\title{
Method for Simultaneous Determination of Creatine Phosphate and Adenine Nucleotides in the Intestinal Smooth Muscle of Guinea-pig Taenia Caeci using High- performance Liquid Chromatography
}

\author{
Isamu Endo, Makoto Utsugi, Tadahiko Suzuki and Hideaki \\ KARAKI* \\ Terumo $R \& D$ Division, Shibuya-ku, Tokyo 151 and ${ }^{*}$ Department of \\ Veterinary Pharmacology, Faculty of Agriculture, The University of Tokyo, \\ Bunkyo-ku, Tokyo 113, Japan
}

\begin{abstract}
Endo, I., Utsugi, M., Suzuki, T. and Karaki, H. Method for simultaneous determination of creatine phosphate and adenine nucleotides in the intestinal smooth muscle of guinea-pig taenia caeci using high-performance liquid chromatography. Japanese Journal of Smooth Muscle Research 24 (2) 127-130, 1988_ A method for simultaneous determination of adenosine $5^{\prime}$-triphosphate (ATP), adenosine $5^{\prime}$-diphosphate (ADP) and creatine phosphate (PCr) by high-performance liquid chromatography is described. This method was applied to the isolated intestinal smooth muscle tissue of guinea pig taenia caeci weighing approximately $30 \mathrm{mg}$. It was found that one $\mathrm{g}$ of the muscle tissue contained $3.55 \mu \mathrm{mol} \mathrm{PCr}, 2.40$ $\mu \mathrm{mol} \mathrm{ATP}$ and $0.477 \mu \mathrm{mol} \mathrm{ADP}$.
\end{abstract}

\section{Introduction}

Muscle contraction is dependent on the source of free energy driving contractile filaments and other active processes. This source includes adenosine $5^{\prime}$-triphosphate (ATP) and other so-called high-energy phosphates such as creatine phosphate ( $\mathrm{PCr})$. In smooth muscle, this source is so small that, even under resting conditions, the preformed energy source could suffice for only a few minutes in the absence of ATP synthesis via intermediary metabolism. Thus, the contractility of smooth muscle is strongly related to the amount of available energy and it is quite important to know the changes in energy metabolism to understand the smooth muscle function (for review see Hellstrand and Paul, 1982).

ATP and PCr contents of smooth muscle have been separately determined utilizing the luciferine-luciferase luminescence (Jabs et al., 1977; Karaki et al., 1982). Recently, methods for simultaneous determination of $\mathrm{PCr}$ and adenosine nucleotides were reported using high-

Accepted for publication, March 22, 1988

遠藤 勇, 宇津木 信, 鈴木 忠彦：テルモ株式会社技術開発部，

唐木 英明: 東京大学農学部家畜薬理学教室, $\bar{\top} 113$ 東京都文京区弥生 1-1-1 
performance liquid chromatography (HPLC) in cardiac muscle (Harmsen et al., 1982 ; Bedford and Chiong, 1984). In the present report, a sensitive, simple and reliable method is described for simultaneous determination of $\mathrm{PCr}$ and adenine nucleotides in the intestinal smooth muscle of guinea-pig taenia caeci.

\section{Methods}

\section{Equipment}

The HPLC system was a Trirotor III (Japan Spectroscopic Co. Ltd., Tokyo) consisting of a pump, a system controller, a variable loop injector (VL 613), and a wave length-selectable detector (Univec 100 III) set at $230 \mathrm{~nm}$.

Chromatography was performed by an anion-exchange column (4 $\mathrm{mm}$ internal diameter and $50 \mathrm{~mm}$ length) packed with Shim-pack WAX-I (Shimazu, Tokyo) using mobile phases of $2 \mathrm{mM} \mathrm{KH}_{2} \mathrm{PO}_{4}$ (pH 5.0, buffer A) and $750 \mathrm{mM} \mathrm{KH}_{2} \mathrm{PO}_{4}$ (pH 5.0, buffer B). Flow rate was 1.0 $\mathrm{m} l / \mathrm{min}$ and the elution started with $100 \%$ buffer $\mathrm{A}$. In the first $20 \mathrm{~min}$, buffer B increased at a rate of $0.5 \% / \mathrm{min}$, followed by an increase of $18 \%$ buffer $\mathrm{B} / \mathrm{min}$ during the next $5 \mathrm{~min}$. This was followed by elution with $100 \%$ buffer B for 10 min and then with $100 \%$ buffer A for 40 min. These procedures were programmed with system controller. The sensitivity of the detector was usually set at 0.16 a.u.f.s. and the oven temperature at $45^{\circ} \mathrm{C}$.

\section{Reagents, standards and procedure}

PCr (disodium salt hydrate), ATP (disodium salt hydrate), adenosine $5^{\prime}$-diphosphate (ADP, potassium salt hydrate), and adenosine $5^{\prime}$-monophosphate (AMP, sodium salt hydrate) were purchased from Sigma Chemical Co. Ltd., Dorset, U.K.

Male, Hartley guinea-pigs, weighing approximately $250 \mathrm{~g}$, were stunned and bled and taenia strips of approximately $30 \mathrm{mg}$ weight were dissected from caecum. The muscle strips were equilibrated for $60 \mathrm{~min}$ in a physiological salt solution of the following composition (in $\mathrm{mM}): \mathrm{NaCl}, 136.9 ; \mathrm{KCl}, 5.4 ; \mathrm{CaCl}_{2}, 2.5 ; \mathrm{MgCl}_{2}, 1.0 ; \mathrm{NaHCO}_{3}, 24.0$; and glucose, 11.1. This solution was continuously bubbled with a mixture of $95 \% \mathrm{O}_{2}$ and $5 \% \mathrm{CO}_{2}$ at $37^{\circ} \mathrm{C}$ and $\mathrm{pH} 7.4$. After a $60 \mathrm{~min}$ incubation period, muscle strips were quickly frozen in acetone dry ice at $-78^{\circ} \mathrm{C}$ and stored at $-80^{\circ} \mathrm{C}$ until analysis.

Frozen muscle strips were homogenized with Tenbroeck tissue grinder (Wheaton, USA) in $2.0 \mathrm{~m} l$ of $0.9 \mathrm{M}$ perchloric acid at $4^{\circ} \mathrm{C}$ for approximately $5 \mathrm{~min}$. The homogenate was centrifuged at 2,000 $\mathrm{g}$ for $5 \mathrm{~min}$ at $-10^{\circ} \mathrm{C}$ and supernatant was neutralized with ice-cold $3.75 \mathrm{M}$ $\mathrm{K}_{2} \mathrm{CO}_{3}$. The neutralized extract was centrifuged at $2,000 \mathrm{~g}$ for $5 \mathrm{~min}$ at $-10^{\circ} \mathrm{C}$ to remove insoluble potassium perchlorate and a $200 \mu l$ aliquot was applied to the HPLC.

\section{Results}

Fig. 1A shows the separation and sharpness of the peaks in a chromatogram of a standard solution containing $20.0 \mathrm{nM} / 200 \mu l \mathrm{PCr}, 10.0 \mathrm{~nm} / 200 \mu l$ ATP, $2.5 \mathrm{nM} / 200 \mu l$ ADP and $2.0 \mathrm{~nm} /$ $200 \mu \mathrm{l}$ AMP. The duration of the run was $55 \mathrm{~min}$. The limits of detection, based on the signal-to-noise ratio of 3 , were $0.136 \mathrm{nmol}$ for PCr, $0.029 \mathrm{nmol}$ for ATP, $0.011 \mathrm{nmol}$ for ADP and $0.014 \mathrm{nmol}$ for AMP. 

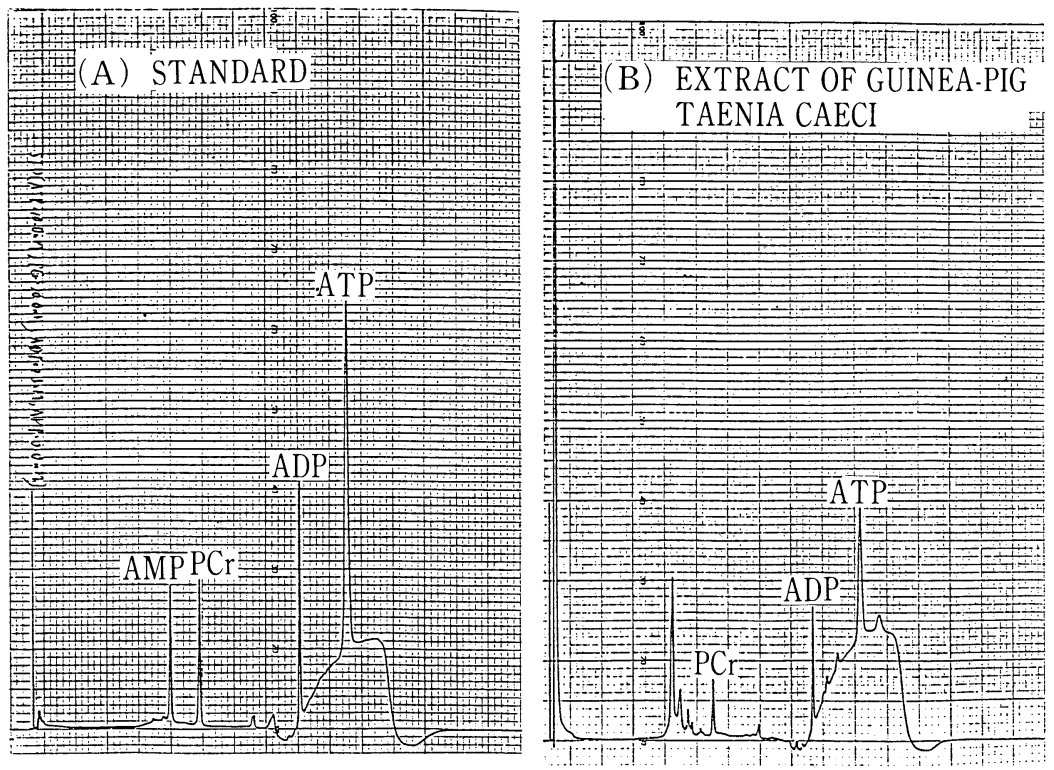

Figure 1. Chromatogram of standards (A) and an extract of intestinal smooth muscle (B). The duration of run time was approximately $55 \mathrm{~min}$. $\mathrm{PCr}$ : creatine phosphate. ATP, ADP and AMP : adenosine $5^{\prime}$-tri-, di- and monophosphate, respectively.

A typical chromatogram of an extract of the intestinal smooth muscle of the guinea-pig taenia is shown in Fig. 1B. In this preparation, peak for AMP was not identified because of the interference by impurities in the extract. Averaging the results of similar experiments, it was found that the taenia strips contained $3.55 \pm 0.40 \mu \mathrm{mol} \mathrm{PCr} / \mathrm{g}$ wet wegiht $(\mathrm{n}=6), 2.40 \pm 0.09 \mu \mathrm{mol}$ ATP $/ \mathrm{g}$ wet weight $(\mathrm{n}=6)$ and $0.477 \pm 0.023 \mu \mathrm{mol} \mathrm{ADP} / \mathrm{g}$ wet weight $(\mathrm{n}=6)$.

\section{Discussion}

In the present chromatographic method, PCr, ATP and ADP were simultaneously determined with a sensitivity which is high enough to detect these compounds contained in a small piece of the isolated intestinal smooth muscle tissue of the guinea-pig taenia caeci. The valuses obtained with this method were similar to those measured by other methods (Butler and Davies, 1980 ; Karaki et al., 1982). Although slight changes in base line were regularly observed, the magnitude of which was almost the same in each run and this change did not interfere with the determination of these compounds. By shortening the run time and by looking for the conditions that simultaneously determine creatine as well and that separate AMP from other impurities, the use of HPLC may provide a more convenient method to examine the energy metabolism in smooth muscle and other tissues.

\section{References}

Bedford, G.K. and Chiong, M.A. (1984) High-performance liquid chromatographic method for the simultaneous determination of myocardial creatine phosphate and adenine nucleotides. $J$. Chromatogr. 305 : 183-187. 
Butler, T.M. and Davies, R.E. (1980) High-energy phosphate in smooth muscle. In: Handbook of physiology, Section 2, The Cardiovascular System, Vol. 2. Vascular smooth muscle. Edited by Somlyo, A.P. and Sparks, H.V. Williams and Wilkins, Baltimore, P. 237-252.

Harmsen, E., de Tombe, P.Ph. and de Jong, J.W. (1982) Simultaneous determination of myocardial adenine nucleotides and creatine phosphate by high-perfomance liquid chromatography. $J$. Chromatogr. 230 : 131-136.

Hellstrand, P. and Paul, R.J. (1982) Vascular smooth muscle : relation between energy metabolism and mechanics. In: Vascular smooth muscle; metabolic, ionic, and contractile mechanisms. Edited by Crass, M.F. III and Bernes, C.D., Academic press, New York, 1982, pp. 1-35.

Jabs, C.M., Ferrell, W.J. and Robb, H.J. (1977) Microdetermination of plasma ATP and creatine phosphate concentrations with a luminescence biometer. Clin. Chem. 23 : 2254-2257.

Karaki, H., Suzuki, T., Ozaki, H., Urakawa, N. and Ishida, Y. (1982) Dissociation of $\mathrm{K}^{+}$-induced tension and cellular $\mathrm{Ca}^{2+}$ retention in vascular and intestinal smooth muscle in normoxia and hypoxia. Pflügers Arch. Eur. J. Physiol. 394 : 118-123. 